\title{
Wole Soyinka's Ake and African Philosophy of Culture
}

\author{
Maduabuchi Dukor* \\ Department of Philosophy, Nnamdi Azikiwe University, Awka, Nigeria
}

*Corresponding Author: Maduabuchi Dukor, Department of Philosophy, Nnamdi Azikiwe University, Awka, Nigeria

\section{INTRODUCTION}

Ernest Emenyonu had said wisely that literature of a people is more or less an "imaginative recreation of a people's account of their social, cultural, political and economic perspectives of a given time and place".(Nnolim, 2015:30) The social and the cultural as an encompassing worldview including the political and the economic is here arrayed to crystallize the sublime philosophical perspectives and literary aesthetics out of a clash of civilizations, the rhythm and contradictions of traditional and natural environment in Ake and how they collectively and generally became a burden to one's curiosity in seeking to understand the other, the local, then the foreign or invading white man's modern views, nay acculturation and enculturation.

Therefore, Ake is a non-fiction literary narrative and commentary which again beyond Soyinka's childhood experience, is a philosophical and literary appreciation of the beauty (aesthetics) of raw traditional environment and natural language in the epistemological metaphysical, ethical and ontological nuances. Moreover, much deep sitted in this avangvard philosophical anthropology are extant theories of a canon of African literature in terms of Theistic Humanism (Dukor, 2010:222-224) which constitute virtually the sublime and Africanity of an African literature.

Soyinka literary work illustrate how "the sprawling, undulating terrain of Ake hosted the personage of Christian God from the basement of Itoko and the traditional cockpit of a chief's stable with live horses near the crest of the hill...". (Soyinka, 1981:1) Advertently or in advertently, this is the mission statement of a great experience experientially that informed the personality of Wole Soyinka and the philosophical anthropology of an colonial and post-colonial African literature. It would have been otherwise as the issue has to do with the cradle of civilization. Imagine how the elders in Things Fall Apart, (Achebe, 1958) would be revolting when St. Peter's Anglican Church was build at the center of a virgin traditional and chieftaincy relics. In the mist of the world of tradition, not paganistic world as the white man would argue, were flickers of Christian symbolismic activities from canon to canon's house, Bishop to Bishop's court, Headmaster to his school all of which together become a colonial infusion in an otherwise, spirited interested and accompanying ritualistic traditional environment infested with nature's cores and rainy season's snails.

\section{AKe's Theistic PANPSYChic Humanism AND ANIMism}

The young Wole had to contend with nature and spirits (panpsychism) of the environment, the ghommids, out of spirit of adventure with his family members in the dead dark to quench the traditional appetite for snails. It was an encounter with the under or other world which his mother's uncle was in the lead to rebuff with an exemplary Christian faith which his mother manifests clearly. J.J. Ransome-kuti would hold out his Bible and order "Go back!" to the ghommids (Soyinka, P.7). It baffles a curious and enquiry mind how and why a Bible with a corresponding linguistic force and energy could repel the equal and opposite force and energy of the spiritual potency of African world (Theistic panpsychism). This is where faith, spirit and matter are in ubiquitous tensions that demand the attention of the ontologists, physicists and religionists. But because the author is neither of the above the problem is left hanging, howbeit to the satisfaction of an anthropologist. However, "Wild Christian" is a reference to Soyinka's mother whose symbolic courage and discipline is an added energy or force to make 'faith' pragmatic. 
In the clashes between western and African civilizations mirrored in Ake's santillating religious and metaphysical paradigm shift, Egungu, ghommides, spiritual arrows or divine sparks or more symbolically, mortars and ammunitions were projected in defence against Rev. J. J. Ransome Kuti who was seen not only as Christian coward but also a Christian priest and agent of enculturation, acculturation and destruction of his own land and universe.

At Ijebu Village where he had scheduled to evangelize he was warned because there would be egungun procession. He defied the warning, and the egungun in reaction to the profany moved closer to the main door of the church then tapped on it with his wand three times" (p. 9) and the building collapsed. Rev. J. Ransome Kuti demonstrated faith and discipline in this material particular, but it did not work. The message is clear. Traditional authority could do more. This immediately demonstrates that the faith and discipline (p. 8) that always abided in 'Wild Christian' (Soyinka's mother) is only a hallmark of a good Christian.

When Sanya came home after a night or so snail hunting he became sick and only became well again after the spirits of the village night were appeased through a feast of Agidi and Ekuru known as Saara for children by the old woman, native doctor, so to say, who brought some of the feast condiments to 'Sanya's sick-room, plus a pot of cold water and cups locked the door on him and ordered everybody away (p. 11). When Sanya was confirmed well, it was also concluded that he was an ero, an agent of the spirit world interposed even as Bukola, the book seller's daughter was also a celebrated member of the spirit world, "one of the denizens of the other world where the voice was caught, sieved, re-spun and cast back in admonishing copies, amulets, bangles, tiny rattles and dark copper-twist rings earthed her through ankles, fingers, wrists and waists. She knew she was abiku" (p. 16).

The narrative of $A k e$ 's world throws back the realities of African traditional world views of theistic pansychism and pantheistic animism which is by no means neither deistic nor atheistic in liturgy. The concept in abiku or ogbanje (in Igbo), that is, a 'born again person' is not an outright indictment of any monotheistic religion but appreciates that there are God and gods. These are what Wole Soyinka is rather not interrogating but he is narrating in a backward utopian manner the critical spirit exhibited by his father's in-house dialogue in the company of the Bookseller, Pa Delumo, Wild Christians and others; a critical attitude of philosophy which like the Socratic village square conversation in the ancient Greece held out God and his attributes for questioning.

However, the good, the bad and the ugly had their semblances in African traditional values. Even an interview for entrance in Government College Ibadan would betray this consciousness, as two boys from Ijebu came with African mystical power concoction, buried near the school in order to outsmart the students in the Entrance examination. Exposed were their amulets, black powder wrapped in a piece of paper..." (P. 188). Consistent with this weird practice and of course African existential tradition was the mysterious portions incised into Wole's blood stream by his father's visitor (p. 188), all with eloquent sense of African world view, cosmology aimed at self-protection. This cosmology has been expressed as either animism or animanism which means "the belief in impersonal spiritual power or a life-fore pervading all things (Parrinder, 1976: 21).

It is a cosmology, an African common world view based on Theistic Humanism, practical Theism, transmitted through the gods and spirits for enhancing humanity. It is therefore not surprising that when the prospective candidates for the interview became rattled by the potency of the Ijebu boys' African power, they muttered thus - S.M.O.G. (Save Me O God). This is Theistic Animism in action.

Yet the struggle or competition for spaces in a Government College is strange to Rev. A. O. Ransomi Kuti whose school Abeokuta Grammar School should be a preferred one because it was based on the foundation of building character through caning than the former that teaches pupils "sir" (p. 192). while according to Mr. Kuti only "slaves say sir" (p. 192).

But the most interesting about this traditional society is its sustained interest and curiosity about masquerade, egungun and its festival. The vivacious play boy Osiki admirably had an egungun, to Wole's surprise, which sparked off chains and series of debate about the ontology of egungun and interrogations onto the supernatural world and its connection to man and earth. "I knew that the egungun were spirit of the dead. They spoke in cultural voices and use to be feared even more than kidnappers" (p. 31). This metaphysical proposition is no less subsumed in the cultural tapestry and matrix of nearly all nationalities and tribes in Black Africa, more especially with Yoruba neighbours 
such as Edo, Itsekiri, Ijaw, Egbira and Igbo of Southern Nigeria. The masquerade, egungun are watched by males; women mustn't come near" (p. 32). Egungun do not speak English, but indigenous language unto which they died, as spirits of the ancestors of the irony. In contrast, the figures of three white men dressed in robes behind the altar of St. Peter's Church could not have passed as egungun because they were not the ancestors of the land, but the vaulting imagination of Wole's curiosity placed the District Officer, who might have been buried in a nearby convetery, among the ancestors, hence he was in egungun robes. The dialogue on the masquerade phenomenon continues in the young Wole's mind as a subconscious play out so much so that when attention is on him, it is like he has become a masquerade.

\subsection{Ogboni Cult}

There were institutions of culture and tradition within the society and the surrounding mystique of Alake's palace like Ogboni cult and men's patriarchy. The connotation of the palace and the Ogboni enclave betrayed their symbiosis and strong hold on the entire society. "The Ogboni slide through Ake like ancient wraiths, silent, dark and wise, a tanned pouch of Egba history, of its mysteries, memories and insights, rhudded through on warriors' feet, defiant and raucous, broad and compact with unspoken violence" (p. 2003). The cult and its members possess wierrd silence and unspoken prowess. Although, reportedly laden in wisdom, experience and cunning, they were all alleged to be child kidnappers whose "haul was essential, to some of their rites and ceremonies (p. 203). They use and wore weird charms. They were fearful and fascinating.

"In the Ogboni reposed the real power of the king and the land, not that power which seemed to be manifested in the prostration of men and women at the feet of the king, but the real power, both supernatural and cabalistic, the intriguing, midnight power which could make even the king wake-up one morning and find that his house posts had been eaten through during his sheep" (p. 203).

They control the Oro (masquerade) cult whose bull-roarer sent all women panicking into the first available houses for refuge. The king was both a a traditionalist, an Ogboni man and a Christian. "When the old king died, his heart and liver were removed and the new king was required to eat them" (p. 205). And on sundays, he would take his special sit in the church. That, euphemistically is the introjection and twists of tradition and Christianity.

\subsection{Headmaster: Rain Ontology and Proof of Existence of God}

Wole's childhood experience is not only about romantisization of the past, and critical dialogue reminiscent of Socrates' dialogue with his pupils and friends like Plato, was also a life plot involving his father (Headmaster) mother, friends and teachers. His father was the Socrates of his time listening in conservations, asking questions, intervening at confusing junctures and postulating synthesis out of thesis and anti-thesis. On a clear and distinct argument with premises and conclusions the ideas of rain and water were deciplered with eloquence of critical thinking and logic. What Wild Christian, his mother, describes as 'see-saw argument' (p. 54) or long-protracted, tortuous dialectics or dialogue began with the issue of rain.

'May be you are not afraid of rain but it does not mean you are not afraid of water, said father

'Is rain not the same as water' Wole demanded

'Rain means water, but water does not necessarily mean rain' said father

'But there can be no rain without water' Wole protested.

'True. But there can be water without rain' said father.

'The water came from the rain in the first place didn't it? Wole replied

'Ah, that is where you are wrong. Rain actually comes from water.

It is because of the water that rain is caused' (p. 54).

'Didn't God create them both separately?' Wole asked. 
'You will find that the Bible tells only part of the story. After God created this and that, he still left them to react with one another in their own ways. There are what we call the laws of nature, that is when the question of how rain is formed comes in', said father.

'All right. Why has the whole town been saying prayers for rain? Does that not mean God is still creating rain when he likes? Wole inquired?'

His father then reflected conclusively: 'Remember this. Even after he has created things on earth and given them their own working lens, as the creator he can still interfere' for instance he can quicken up the processes or slow down' (p. 55).

These are manifestly and clear eristic arguments and question and answer conversations or Socratic argument in the tradition of Plato or Hegalian thesis, antithesis and thesis. Wole Soyinka's narration of his childhood experience leans profusely on natural language of proposition and traditional logic. It is our duty as logicians, therefore to formalize the interlocutions in valid and invalid argument forms since there are extant premises and conclusions in the arguments about the relation between rain and water and the place of God in the scheme:

Rain means water, but water does not necessarily mean rain.

There can be water without rain therefore rain actually comes from water.

God created this and that on earth.

He gave them freedom to react among themselves. Therefore that is how rain is formed.

God created things on earth and gave their own working laws. As the creator he still interfere. Therefore He can quicken up the processes or slow them down.

The logical sequence above yields what logicians call premises and conclusions in argument forms and since Ake is a traditional African set-up, Wole's father could have been a sagacious African elder, belonging and living out a traditional African intellectual class, albeit, educated and Headmaster of western modeled school, but who in that traditional environment could not have read Socrates, Plato and Aristotle not to talk of the dialogues of Phaedo, Republic and so on.

There are also interesting syllogistic argument forms inferable from the conversations and dialogues between Essay and his son, Wole. According to Essay:

God created things on earth and gave them there own working laws.

As the creator He interferes in their working laws by quickening or slowing them down.

Therefore He God interferes in their working laws by quickening or slowing them down.

These are syllogisms for the existence of God inherent in Wole's father's submissions which are the same logical genre with the ontological proof for the existence of God thus:

God is a perfection

Everything that exist is perfection

Therefore God exists

These are predications based on natural language of Yoruba to English nay, $\mathrm{Pg}, \mathrm{Px}, \mathrm{xPx}$, and Gx instantially enumerated where designators, quantified basic predicates are extemporarily are expositions of an African sagacies teacher, guardian and elder on ontology, metaphysics and reality. 
Predication as sense-condition of a proposition is transcribed skillfully from Yoruba to English as the dialogues, conversation and interrogation proceeds among the young Wole, his father, Headmaster and co-interlocutors.

\section{Patriarchy, Tradition And COMmunity}

In Ake the sense of community, the church, church-Tower, Boobab, bell house, playing field, Guarantee, Rocks, gardens and so on dominated and animated the interactions and discussions as the extended objects of the world of reality and imagination recall forte and frequently the sense of the history of Ake as the germinating environment of brutalial modernity in the midst of subliminal tradition and culture. It is a closure, a self-confident inclusive and serene education community without cultural regimentation and borders. Sunday school with Biblical references to things that in real life and imagination go on as informal and formal education. The mythical, the historical and the stereotypes were subjects in the discussions such as Jonah in the Bible, Father's Gun, Mother's Medicine Kitchen utensils and all the eateries in a day. None of these escaped the young Wole's imagination and intrusive provocative thoughts which often sparked rebellious intrusions, inquiries and poking in breach of traditional ethics and family moralities. Ake ambience is an inclusive culture eminent in the aesthetics of the innocence, order, submissiveness and sublime philosophy.

Yet the image of patriarchy, though not necessarily misogyny, captures the phenomenological thread that strikes a defining principle of Yoruba culture and Ake community in particular wherein lies the struggle of the young Wole to escape from the box of traditional reason or logic to a wide horizon of alternative knowledge that $\mathrm{x}$ or $\mathrm{z}$ is the case. This is an encounter of ubiquitous nature which the psychoanalytic questions Wole is consistently visited with by mother or father are issues some theorists and cultures cannot let go and as such well represented and articulated by Wole in his incessant drudgery and revolts to unexplainable values, myths and stereotypes. The patriarchal society is intimidating of not only woman, as constantly observed in the withdrawn and genuflecting attitude of the Wild Christian when the voice of the husband is high, but also the children who must be obedient, and precautionary in learning the successful ways of their fathers and elders. Ake therefore imposes a system of values created by man who presumptively possesses rationality and duty over women who are emotional and occupies a fixed place in reality as cats and birds or at best cows (Nietzsche). For the young, like Wole, the patriarchy is an admixture of pleasure and pain, blessings and hindrances as this is either repressive or conducive. But for Freud, repression grooms civilization as restrictions imposed by culture and internalized at Wole age forms the superego and help to mould the individual in accordance with societal demand. (Freud,1961: 44 \& 65) But for Bertrand Rossell this is an anti-creativity culture which stifles scientific progress and individual development. (Russell, 1932:10-20) Women and children are, therefore, not transcendent but immanent in the patriarchy for sustenance of man's, so to say, acclaimed values. Wole inquisitive gate and critical attitude is abhorrent to the unquestioning standards of the society and often result to his conflict with moral values which is regularly resolved by the much expected obeisance of the woman, and to the children predilections.

The patriarchy model of husband and wife social intercourse interfacing the children upbringing in a community of coercive values was exalted in Ake. Wild Christian and Essay's domestic lifestyle were interesting, that is, patriarchy vaulting transcendence and the woman ignoble repressive immanence which Simone de Beavoir would describe as misogyny in her second sex. He would agree, with Frazer that "men make gods and women worship men" (De Beavour, 1949) But that is not the only stuff of African Ake's culture which ultimately hinders but preserve orderliness and purity as sublime moralities. Traditional moralities are supervening intermittently assuming a binding chord in the family and society. It was a society ruled by punishment, admonition, reprimand and cajolement often represented by the symbolic emi esu, the spirit of the devil (Soyinka, p. 80). To observe the replication of the spirit of the devil in an individual instead of in the wood or in the forest is all together reprehensible.

Allegation of being possessed by emi esu (spirit of the devil) is symbolic reprimand and warning even though in the Ake's cosmology the concept is an existent being in the supernatural world. No parents wish their child evil, but it is foreboding of future evil not to be a true human being but a replica of devil. Punishment is often administered to keep off the threat of devil in the household. 
'Sharing' is an important value system in the Essay's household, to which Wole invariably partook with regard to sleeping space, mat, play ground, eating and chores with the exception of occasional truancy bordering on inquisitive temptation to handle his father's hunting gun and straying into the woods or forest for snail search in the company of others or alone. It is not straight forwardly a generalized domestic practice as Wole would assert that sleeping in a particular place or condition generates the wildest dream' (p. 8), but it does not suggest on inductive instantation that bad sleeping habits are always accompanied by bad dreams. And similarly wetting or urinating on the sleeping mat is also constantly conjuncted with sleeping rhythms, a habit which is shameful and highly abhorred with respect to children of certain age. A victim of wetting on the mat would be subjected to a dance of shame (p. 87). And statement of shame would be fired at him or her such as; "Look at her. Sixteen and she still wets the mat like a newly born" (p. 87). Punishment for other infractions like stealing could also attract indiscriminate whipping by urchins. In average household, so to say, the mother is often encouraged to participate in disciplining or whipping a derailing child as Essay would often grumble to Wild Christian over Wole: "You should have flogged him. Why bother me" (p. 91). Indeed family tit-bit is a sing-post of Wole's childhood experience with often occasional outreach to environmental friendliness and activities in St. Peter's church with its surrounding creeks, rocks, gardens, cenotaph bell flowers and funerals accompanied by folk music. These were consolidated post colonial Africa that dies hard but has died because of corruption.

In Wole is an immanent force to break out the box, think out of it and reach out to the sky or the edge of knowing. His battle is the battle against a closed society closely knit together by blood ties and customs. Relationship is bounded existentially by culture and values, hence every member of such society must submit to the authority of the culture, customs and taboos, and the authority of the gods and collective unconscious. As one will observe and mostly conclude, Wole's childhood experience is an epitome of clash, between freedom of creativity and determinism of stagnancy.

\section{Phenomenology and Change}

Ake as a classic episodidactic, epistemological and paradoxical narrative book is a window into the restless, enigmatic and animated clashes between Wole's Freudian id and ego in response to objects and values of the external world. The phenomenon of 'change' had a rightful place and interest in his subliminal consciousness. Everything became a phenomenon subject to exploration to him, as spectre of changing phenomenon including man, organism, object and the external cosmos overwhelmed him like the corperniccus revolution and Kantian critical philosophy where the subjective mind determines sustenance and planetary movement. (Capleston, 1960:225)

Change was impossible to predict... features appeared where they had not been, vanished where before they had become inseparable from our existence.... Every human being with whom we came in contact, Tinu and I, would change...." (Soyinka, p.93).

A stream of consciousness and a wondering mind as this would suggest, is a phenomenological ephoche of Hurssell, "experiences of consciousness" (Heidegger, 1956:239). It is a thinking out of the box, a methodic doubt reminiscent of Rene Descartes meditations on reality of the external world (Descartes, 1979:45-56).

There is an emphasis on change as a phenomenon. Wole chronicled other changes in his epistemological space and environment comprising his parents house, compound, Ake town and the entire Yoruba society in continuing trajectory; change in the birth of Dipo, his younger sibling occasioned by the pregnancy of Wild Christian, Wole's mother, change in the family house or domestic change, when the arm chairs and the drink stools went back, a change had taken place (Soyink, p. 94). Change in homilies embroidered and framed hanging on the walls and streets: "Ebenezer: hither to had the Lord helped us" (p. 94). "Honour thy father and thy mother" (p. 94) Remember now thy creator (p. 94). The Lord is my shephered (p. 94) and so on. These homilies are didactic locutory sign posts of good and moral life. Their functions were character building in a moral society. Quoted from the Christian scriptures, they were vestiges of Christian moral teachings and influences on the onto-theological African culture. These homilies were however immutable and immune to physical and biological changes. 
Death is a bizarre dimension to the change young Wole is perceiving all around which unfortunately had to do with his younger sister who instead of change in age failed to mortal change of death. This was a change in Folashade which their parents battled to stop but was inevitable to the utter curiosity of Wole.

Part of the ominous and omnipresent change was decay in houses and environment of the school and Ake community in general. A sense of animism usually accompany such general decay and backwardness and Wole was deep into much animistic belief to warn anyone who touches his guava with threat of its spirits thus "If you touch my guava tree, their twin will visit you at night" (p. 99). The preeminence of change handsomely recalls the ancient Greek philosopher, Heraclitus who says that everything is in a flux (Warner, 1958:25-29).

The ambience of Wole Soyinka parental home and Ake wore this face of change in every genre including biological, physical, political and spiritual even as Hitler's world power and sundry spiritual issues percolated discussion and issues in conversations. This is also a somewhat conjurement of power as a spiritual entity, apart from Wole's physical exertion in a fight and Hitler's power in the world. The personality of Wole as a domineering figure in Soyinka's household tends towards adventurist changes and the recognition of a visiting goddess is a pointer to the prevailing culture of animism in Yoruba land.

\section{Clash of Cultures and Westernization}

Ake was symbolic and witness of the dawn of another dimension of western civilization which Wole caricatured as magic spell and an invasion. In Essay's family as well as in Yoruba land there was a sudden evolution from the use of oil lamps to use of electric light with switches and bulbs and from gramophone to Radio which was not only a symbol status but also medium of information and news broadcast. The Radio was by any stretch of imagination an oracle, so mystified but intelligible that neighbouring people would gather in Wole's father's house to listen to news as it blows from the mystical object, radio, with uninterrupted mien. The radio had a jingle, 'God save the king' at intermittent hours apart from the news bulletin. The old order of gramophone with voices of Denge, Ayinde, Bakare, Ambrose Campbell and some Christians carol were gone and new order emerged instantly symbolized by the voice of song:

One who speaks without expecting a reply

Electricity, government light

Umbrella or the Lagos elite

Redifusion, white man lies (p. 108)

This is a repertory of episodes about the 'box', the radio which Wole romanticized as both useful to the villagers, the colonized and as instrument for colonizers in their mission. The box is not a metaphor as such but a garget through which the waves inform and entertain the local folks on the ravages of the World War II exacerbated by German Hitler. Among other "miracles" and novelties in Ake were the white man's fashions and technologies like Aeroplane. When it first flew across Ake it conjured the imminence or image of Armageddon as 'flocks of children watched in fascination, ran about the fields and the streets, following the flying miracle as far as they could" (p. 109).

Information technology, a symbol of Globalization was displayed, as "Hitler monopolized the box... we were drawn more and more into the expanding arena of menace. Hitler came nearer home every day" (p. 109). Hitler was in the news always so much so that one Pa Adatan, a traditionalist, ritualist and erratic boosted that he could confront Hitler personally and ultimately end the war. Narrating his powers to Wild Christian, Wole's mother, the ritualist said, "when dey come mama, den go know say there be black man medicine" (p.110), Hence, when the colonial Nigerian Army truck pulled up in the vicinity of Wild Christian shop Paa Adatan was agitated and began a war dance and song thus:

\section{Ogun Hitilad Ake}

\section{Eni la o pa Bete (P.110)}

The colonial soldiers mostly black with admixture of whites, perhaps, were amused about children's fascination in seeing them and the macabre dance of $\mathrm{Pa}$ Adatan. But that is not all about the curious 
spectable of clash of cultures or enculturation. It was as if $\mathrm{Pa}$ Adatan was furious over the invasion by strange colonial soldiers into the typical traditional village setting of Ake. The soldiers responded by wrestling with him and tying him down, demobilized until he could utter threat no more. They left him castrated and bound with rope. When it seemed no one could loose him from the prison rope, it was Wild Christian, Wole's mother that did the miracle of unbounding Pa Adatan.

Wild Christian was reckoned in Ake as a bold woman whose exploits manifested in political and religious domain. She was a disciplined woman who ran a shop of foods and who also never failed in her domestic chores and loyalty to her husband. She was an African lady in the true sense of cooking and serving food to her husband and children, and any visitor around the material time. Ake community was however, boistenous with many scenes including the vestiges and horrifying episodes of Hitler and enlistment or conscription of black people, to fight in the second World War at Burma.

\section{Nature, Culture and Tradition}

Ake witnessed a compendious dramatic exhibition of conflicts, acculturation and enculturation going on between Yoruba world views and Judeo-Christian western world views even inside and out of Wole's parents' nuclear family hood. Wole stood out significantly as a child difficult to bend for either western or African traditional culture. It was an errant show of disrespect for the children of a Headmaster, Wole included, not to "prostrate them-selves in greeting" (p. 126). Isara, a town in Ijebu clan where the parents of Wole hailed from admired the offsprings of the literati but not the reckless show of disrespect encapsulated in non prostration on one's knees before elders. The reading betrayed the sensitivity to cultural mores and the knocks received by parents who failed in their cultural and moral duties.

One Christmas and New Year festivals, in the palace of Odemo at Isara was a tempting, dramatic and interesting episode, as must have been in other Nigerian villages at the time, where children were forced to be at home with the aboriginal cultures. When in the court of Odemo, the king, someone conciliatorily surmised that "they don't even know how to prostrate" another roared "why not?". It was a serious misgiving in popular Yoruba culture not to prostrate before elders.

Prostration was an ethical point rightly made where it had to be made, the palace of the king, where chiefs and elder interact, discuss, wine and dine. But the enduring legacy of the young Wole is his unbending critical mind to uncritical culture, even seldom sacreligious to the name of God. In response to prostration before elders and chiefs he thought:

"If I don't prostrate to God, why should I prostrate to you?

You are just a man like my father, aren't you?" (p. 129).

The altercation provoked by the question of prostration in consequence made Essay, Wole's father to prevail on his children to obey the ethics not only in the village, Isara, but also in Ake where he sourgoned as a teacher.

One pungent feature of the good old days and living in generally most African villages was trekking at a distance, or boarding on lorry truck where available. Journeys from Ake to Isara, vice-versa was punctuated by this transportation module which was the take of traders.

Village life in Africa had its forbiddings; it played out in Isara. Wild Christian was on top of the situation. She would admonish children against greed and against being poisoned. Consequently Wole and siblings were drilled in ways and means of avoiding a hand shake through which poisoning was easily transmitted. This technique was bowing with one's hands at the back; "the more persistently a chance acquaintance proffered his hands, the more resolutely we kept our hands behind bowing respectfully, and looking permanently on the ground" (p. 30). It was a survival and existential game, akin to existential philosophy of authenticity, selfhood and freedom.

The Isara as well as Ake village and natural scenarios were painted as being both crude and innocent to development in terms of shabbiness of the environment where "children's excrete could be passed anywhere" (p. 130), and uncanny habitations in which a faeces were flung or expelled directly by squatting adults - who often were seen defecating with buttocks bared to the bush (p. 131). Apart from the seeming barbaric conception of 'village' life, Wole was in suspense contemplating on other life-patterns like farming and co-habitant of snakes that mingled with kola-nut tree. A snake was eventually killed but the head which was a taboo and poison to anybody that steps on it was buried. 
Broda Pupa, an indigenous hunter savoured the delicacy of the meat of the snake to the astonishment of the children of the Headmaster who were on holidays of Christmas and New Yea.

In the innocence of the natural habitant were the cohabitation of snakes, bees and other predatory animals and birds. The wailer bitten by bees had his "face, arms and neck, swollen to twice their normal sizes...." (p. 137). The setting of Isara or traditional Yoruba or African towns was a scenario of nature's crudity as well as social, cultural and economic gifts. Hunting with catapults, stones, sticks and cudgels subjects the pretatory animals which commune with man to easy kill just like farming on the soil and productivity was nature's beauteous gift. In the nature is a mystery like the biting bees. To this, Wole's mother, the Wild Christian and his father, Essay or Headmaster would react differently'. God moves in mysterious ways" said Wild Christians but for the Headmaster, "Ogun protects his own" (p.140). Wole's father would not believe that Ogun is a pagan's devil, but a god in her own right, benevolent and protective. Wole's father, a western trained teacher in the missionary school was surprisingly but traditionally a believer in one of the African gods. He was a Christian in the town but behind the veneer of his belief or mind was utter dependence on the god in the land of his birth. His wife, Wild Christian seemed to be a practicing Christian.

Father's belief not only prepared Wole physically and spiritually but influenced his belief in the wickedness of witches, sorcerers and any others who are thought to damage the life and health of beings (Parrinder, 1976:28), and as well as the gods of traditional religion and to same extent theistic humanism of African philosophy. To prepare Wole for the Government College or Abeokuta Grammar School, his father had to invite spiritual expert for Wole's spiritual and physical immunity by spiritual bath and immersion, process of undergoing pain and protection from physical and spiritual death. Wole was made to pass through spiritual and physical ordeal of an immersion

"I felt my right ankle suddenly in the grip of a voice.

I looked down and saw the same blade flash into the bush and out again, until the pain in my flesh was no longer defined by movements.

A soothing band encased my ankle, when I looked down I noticed a wide sweat in the mixture of the dish. Binding my ankle now was the strip of cloth which had been soaked in that mixture.

When it was over I disbelieved what a short time it had all taken" (Soyinka, p. 146).

Wole was made strong spiritually and physically, hence the advice goes:

"Whoever offers you food, take it. Eat it. Don't be afraid, as long as your heart says Eat. If your mind misgives, even for a moment, don't take it, and never step in that house again...." (p. 147).

Secondly, "whenever you find yourself, don't run away from a fight. Your adversary will probably be bigger; he will trance you the first time. Next time you meet him, challenge him again. He will beat you all over again. The third time, I promise you this you will either defeat him or he will ran away..." (p. 147).

This is the wish of Essay for his son without whose consent the ritual would have been performed for Wole.

The evolving ambience of Ake town captured the subliminal consciousness of young Wole Soyinka with the mind boggling pictures of the scenes within and outside family house. The smell in and around the town, that of a smashed bedbug, the rattles of crickets and cicades inside the house, the legendary mango tree and its cacophony of nocturnal and social activities conjured with the lunatic love birds - Saro wanke and Yokolu and the traditional fast foods, all supported the religious, spiritual and social significance and ambience of St. Peter's Church, Ake.

In the mist of entrenching westernism, Yoruba, culture however, dies hard as traditional cookeries like Ojo and palmwine wine were incessantly celebrated. Ake town was a beehive of alien and foreign activities ranging from masquerade, egungun, police band, market cries to clang of hand-bells advertising imported wares and products like shawls, combs mirrors, radio, clocks, photo frames and so on (p. 150). In the valupteneous soaring of invading culture the rendition of Dayisi guitar rented the atmosphere in the visible anonymity of social tension in Ake, a conception of the difference 
between light and darkness. Traditional and alien magicians competed for power. The young Wole hand to join the fray as he ventured walking a dangerous spot called Dayisi promenade singing:

For I am a magician

You all must know

You'll hear about me wherever you go

You can see my name in letters large

You can see me perform for a poultry large

For Anthony Peter Zachary white

Is a man who always give delight....

My friends I bid you come and see

What sort of wizard I may be

Come one and all

And join the crowd

And lift your voice in praise loud

For young Wole, these lines of poetic utterance have the potency of forbidding any predatory spirit from attacking him in the night or in any dangerous spot. He feigned magician to add the potency of the power of the words. The Ake centenary Hall was host to magicians, local and foreign competing for power. It was the land of sprints and theistic animism and panpsychism. In the exhilation of power "They burnt incence, transferred volunteers from the audience and sliced their assistants in half in supra-natural exhibitions, using hyppotical enchantments or Abracabras" (p. 151). The magician was the agent of the mysterious Orient - India, Egypt, the three wisemen, Moses and Pharaoh and the plagues (p. 152) while the local challenger from Ake's audience was a replica of Paa Adatan, the famous warrior who challenged the western soldiers. It was a stage set between the power of the Oriental agent, the 6th and 7th Books of Moses and the African power, but at the end, the orient won the mysterious game.

The traditional poetic background and foreground of Ake Yoruba culture was strong. It influenced Wole a lot whose subconscious mind, coincidently inclined to this poetic exhibition. From interests in lessons from teachers, scouting and few fictions he joined the choir practice through his providential benefactor, Mr. Orija. His poetic familiarity with Yoruba classic poems and the Christian Easter "Cantata" (p. 152) were disposable factors, so his father, Essay gave him a node of approval and support in the choir practice. Wole, as it were, became a church member and goer, even though he frivolously spent the money meant for offering on local fast foods and skeptically offered the rest to God he was afraid to confront. He said: "robbing God to pay Iya Ibarapa, used up the pennies we were given for offering on the steaming, peppery glutinous rot of liver, of drinks and twists of cows' insides served by the old woman as church bells signaled the half hour before confronting God..." For Wole and the Yoruba Isara and Ake, Ogun was not God, of the Christian, but almost a god with great and nearer potency. That is why everything is theistic panpsychic and animistic in Yoruba anthropocentric metaphysics including the distant grandmother of Wole, 'the mysterious elder sister of Rev. A. O. Ransome-Kuti

\section{Mrs. Kuti And EGbu Women's Union On Exploitative Taxation}

Ake was the formative crucible of Egba Woman's Union, a movement amorphously and symbiotically evolved from the councelling court of Mrs. Ransome Kuti at Abeokuta Grammar School with the keen, fortutious and ineffable support of her husband Rev. A. O. Ransome Kuti, the school principal and Wole's mother, Eniola (Wild Christian), the wife of the Headmaster in Ake parsonage (Wole's father). Local, literati and non literate, urbane and the rustic women of Egba land swelled the congregation in Kuti's courtyard for councelling, singing and holding enlightening and educative discussions bordering on "hygiene, community development, self-help programmes, market and commodity prices - letters and figures..." (pp. 180 - 181). Most of the young ones among this meeting were the engine and soul of a Great Upheaval over Taxation protest in Egbaland. 
These women complained of being harassed on their way to the Great meeting by Tax officials and soon it became a tinder box. The women were outraged. "It is time we told them. No more taxes. They want to bleed us dry, let us tell them. No more taxes" (p. 184). It was a historical milestone as Egba Women's Union confronted the District officer, Egba Council of Chiefs, Sanitary Inspectors and the Tax Officer's over exploitative taxation that caught the attention of the colonial government. African Women of Egba stock knew their onions; they were illiterate to western ways but knowledgeable in philosophy of life and tradition. But the campaign in a foreign England Newspaper that they led a pauper's existence (p. 192) by Mrs. Kuti spread like wild fire. To investigate this claim British officers visited Egba and confirmed to the contrary that "Egba Women lived in comfort and splendor. Yet, the African Egba Women were exploited through taxes according to Mrs. Kati Campaign in England.

Mrs. Kuti return from Britain coincided with a bubbling and stormy cascade of her initiative, the radical women movement that opposed oppression of women in all its ramifications. The festival that was held in her honour further ignited the flame. An issue based event on return was not uncommon in African society corroded by envy and conspiracy. It was a gay of mammoth crowd following the surprise appearance of a naked woman carrying Igba Ebo (poison concoction) targeted at Mrs. Kuti. This woman, stark naked, with a conspicuous Igba Ebo on her head had penetrated right up to the walls of the mansion (Kuti's) where she would have deposited her evil load but for the vigilance of the night guard (p. 197). Voice of condemnation roared in the compound of the Kuti's with a loud verdict and fingers pointed that this is the handiwork of the same Atupa parlour who signed the letter which says that Egba Women "are all millionaires" (p. 193). It was an unprecedented, diabolical plot to injure Beeri (Mrs. Kuti) through satanic means" (p. 197) but her husband, Rev. A. O. Ransome Kuti (Daudu) and his coterie of sympathizers raced to the occasion. Yoruba African belief says that the woman was naked because he was bathed in a poison which rendered her invisible. However, the ritual must have been defective, "making its effect wear off before her mission was completed" (p. 198). In cossonance with African Yoruba culture, a public open mock show was made of the fetish woman to and from the police station and finally to Ake's palace.

Egba Women's Union became virulent, vociferous and resourceful with the attempted poisoning of Mrs. Kuti, as leaflets kept flying on the subject of oppressive taxation and sundry issues in Egbaland. It gradually transformed into a political resistance against colonialism, a nationalist struggle of sort. The Frenzy of chant - "No more Taxation", was a supportive pragmatic ideology against the white rule on the side line of the nationalist trumpets of Zik, Tony Enahoro, Ibiam, Ojike and the National Council of Nigeria and the Cameroon. Meetings and recitals of how to present the case of taxation were held by the women group.

The suffering and trepidation of an old widow with thirteen grand children in the hand of the tax officers were pathetic. This was the background stage of the riotous visit to the palace of Alake's palace over taxation. In the absence of Mrs. Kuti who was on her way were the leaders including Wild Christian, Wole's mother. They laid siege on the palace until the king himself appeared to listen to them and said, "Nothing can be beyond solution with the group I see before me, so let's get to it. What is the matter in our beloved Egbaland (p. 107). The women, through the leader tried much to convince the king on excessive taxation with the credo; 'Enough is Enough' (p. 107). We women say No more tax! (p. 208). Alake (king) was obviously stupefied but had to interject: "Taxation is as old as human society, can one simply do away with it just like that?" Wild Christian replied, Kabiyesi, over this matter", I wish to implore you to reflect very carefully. Very carefully...." (P. 209). The dialogue was on when Beere (Mrs. Kuti) arrival was heralded with loud ovation followed coincidentally also by the arrival of the District Officer accompanied by policemen. Nerves were fractioned in the altercation between Mrs. Kuti and the District Officer as the groups behind each of them were set for a show down. When the officer angrily admonished Mrs. Kuti to tell his women to shut up, Mrs. Kuti angrily replied: "You may have been born, you were not bred. Could you speak to your mother like that" (p. 211). The District Officer was over whelmed by the women's solidarity shout threatening to cut off his genitals and post them to his mother (p. 211).

The chief's rose to the occasion to subdue the Egbu women who were mobilized against taxation, thinking they would be on top of the situation with the instructional audacity of Ologboni (cult members), then followed by the cult high ranking officer, Balogun. The Balogun of Egba District vilified, scorned and upbranded the women to the ulter consternation of the women folk. In 
retaliation the women led by Mrs. Kuti were alleged to have exerted supernatural powers on him leading to his collapse and half-paralysed. His neutralization left other members of Ogboni in disarray even as "His shawl was snatched, shredded, his wrapping cloth was stripped off him - fan, office, staff, cap all had long disappeared. The Ogboni were flogged with their shawls, fans, and were left only with their undershoors when finally let through a gauntlet of abuse into the palace or back in the direction of their homes" (p. 213). This is the beginning of all women insurgency against not only the Ogboni cult, an exclusive preserve of strong men in Yoruba but also against patriarchy. The strength of the women grew from one level to another, increasing in network, caravans and groups, all emerging from different directions in solidarity with the leadership of Mrs. Kuti (Beere) and Mrs. Soyinka (Wild Christian) chanting war songs drawn from Biblical and Quranic scriptures for abolition of tax and men precipitated Ogboni domination.

The ironical dimension to the decimation and neutralization of Ogboni members was that the Ogboni old man who was given way of escape from the turbulent crisis and iron hands of the women "prostrated himself repeatedly, thanked and blessed Wild Christian profusely. He sped off in his shorts, bundle in hand, leaving his staff behind. He would fetch it the following day, he said" (p. 216). Egba women premeditatively demonstrated invisibility in the face of oppression, fought a war of nationalism against colonial masters personified in taxation and neutralized men's domination, and patriarchy personified in mysogency. Similar tales concerning women abound in black Africa.

\section{CONCLUSion}

Therefore, Ake is a non-fiction literary narrative and commentary which beyond Soyinka's childhood experience, is a philosophical and literary appreciation of the beauty (aesthetics) of raw traditional environment and natural language in the epistemological, metaphysical, ethical and ontological nuances of Ake society. Moreover, much deep sitted in this avanguard philosophical anthropology are extant theory of a canon of African literature in terms of Theistic Humanism, theistic panpscyhic Humanism and Animism, African cosmology and ontology. There are also in this book the sublime and aesthetics of the phenomenon of change in African traditional environment, clash of cultures and extant African school model epitomized by Abeokuta Grammar School.

\section{REFERENCES}

[1] Copleston Federick (1960), A History of Philosophy, The Enlightenment, Voltaire to Kant (London, Continua).

[2] Dukor M., Theistic Humanism of African Philosophy (Germany, 2010).

[3] Freud Sigmund, Three Case Histories (Trans) Philip Rieff, (New York, Coller Books, 1963).

[4] Nnolim Charles, Literary Review Saturday Sun, May 2, 2015.

[5] Parrinder Geoffrey (1976). Africa's Three Religions (London, Sheldon Press).

[6] Parrinder, E.G. (1976). African Traditional Religion (Sheldon Press, London).

[7] Simone De Beauvour, The Second Sex, 1949.

[8] Steve, Fuller (2007). The Knowledge Book (MCGILL-Queen's University Press, Montreal and KingstonIthaca).

[9] Warner, Rex, (1958), The Greek Philosophers (New York, A Men to Book).

Citation: Maduabuchi Dukor. Wole Soyinka's Ake and African Philosophy of Culture"International Journal on Studies in English Language and Literature (IJSELL), vol 7, no. 6, 2019, pp. 22-33. doi: http://dx.doi.org/ 10.20431/2347-3134.0706003.

Copyright: (C) 2019 Authors. This is an open-access article distributed under the terms of the Creative Commons Attribution License, which permits unrestricted use, distribution, and reproduction in any medium, provided the original author and source are credited. 